Buletin Ilmiah Math. Stat. dan Terapannya (Bimaster)

Volume 08, No. 4 (tahun), hal 751 - 758.

\title{
ANALISIS REGRESI LOGISTIK MULTINOMIAL PADA PEMILIHAN ALAT KONTRASEPSI WANITA (Studi Kasus di Puskesmas Sungai Kakap)
}

\author{
Novianti, Setyo Wira Rizki
}

\begin{abstract}
INTISARI
Regresi logistik multinomial merupakan regresi yang digunakan saat variabel dependen mempunyai skala yang bersifat multinomial. Skala multinomial adalah suatu pengukuran yang dikategorikan menjadi lebih dari dua kategori. Data yang digunakan pada penelitian ini berupa data primer tentang karakteristik pengguna alat kontrasepsi di Puskesmas Sungai Kakap. Ukuran data yang digunakan adalah sebanyak 150 dengan variabel dependen berupa jenis alat kontrasepsi, yaitu IUD, MOW, implant, suntik dan pil, sedangkan untuk variabel independen berupa usia ibu, pekerjaan ibu, pendidikan suami, pekerjaan suami, jumlah anak hidup, umur anak terakhir, dan rencana hamil. Penelitian ini bertujuan untuk menganalisis faktor yang berpengaruh terhadap pemilihan alat kontrasepsi dan untuk mengetahui probabilitas pemilihan alat kontrasepsi wanita di Puskesmas Sungai Kakap. Hasil penelitian menunjukkan probabilitas seorang ibu dalam menentukan pemilihan alat kontrasepsi dipengaruhi oleh umur ibu, pekerjaan ayah, jumlah anak hidup, dan rencana hamil. Probabilitas kelompok ibu yang berusia diatas 30 tahun dengan jenis pekerjaan suami terampil, jumlah anak lebih dari 2 orang dan tidak memiliki rencana hamil, untuk memilih IUD-MOW-implant adalah 22,898\%. Probabilitas kelompok ibu yang berusia kurang dari atau sama dengan 30 tahun dengan jenis pekerjaan suami terampil, jumlah anak kurang dari atau sama dengan 2 orang dan memiliki rencana hamil, untuk memilih suntik adalah 94,7562\% dan probabilitas kelompok ibu yang berusia diatas 30 tahun dengan jenis pekerjaan suami tidak terampil, jumlah anak kurang dari atau sama dengan 2 orang dan tidak memiliki rencana hamil, untuk memilih pil adalah 91,509\%.
\end{abstract}

Kata kunci : Regresi Logistik Multinomial, pemilihan alat kontrasepsi.

\section{PENDAHULUAN}

Pertumbuhan penduduk di Indonesia dari tahun ke tahun semakin meningkat. Hal ini dapat dilihat dari jumlah penduduk pada tahun 1971 yang berjumlah 118.000.000 jiwa meningkat dengan pesat menjadi 265.015.000 jiwa pada tahun 2018 [1]. Salah satu upaya yang dilakukan pemerintah untuk mengendalikan laju pertumbuhan penduduk adalah dengan cara penurunan angka kelahiran dengan program Keluarga Berencana (KB) yang dimulai sejak tahun 1970. KB adalah gerakan untuk membentuk keluarga yang sehat dan sejahtera dengan membatasi kelahiran. Keluarga berencana mempunyai dua program, yaitu KEI (Komunikasi, Edukasi dan Informasi) dan pelayanan kontrasepsi. Adapun berbagai macam pilihan alat kontrasepsi yang disediakan oleh pemerintah khususnya bagi wanita, antara lain: pil, suntikan, alat kontrasepsi dalam Rahim (IUD), implant, tisu KB, tubektomi (MOW), cream, jelly dan foam [2].

Program KB dan tingkat kesejahteraan penduduk memiliki hubungan yang erat dan dapat saling mempengaruhi satu sama lain. Pertumbuhan penduduk yang besar dari tahun ke tahun memerlukan tambahan investasi dan sarana untuk mendukung kesejahteraan rakyat seperti sarana pendidikan, kesehatan, perekonomian dan lain sebagainya. Hal ini tentu saja merupakan masalah bagi pemerintah dalam usahanya membangun dan meningkatkan taraf hidup rakyatnya demi untuk menuju masyarakat yang sesuai dengan isi UUD 1945. Pertumbuhan penduduk yang begitu pesat sangat mempengaruhi perekonomian suatu bangsa, karena karena sekarang ini kepadatan penduduk di kota-kota besar di Indonesia mempengaruhi pada tahun-tahun terakhir banyak perilaku kriminalitas yang terjadi akibat penyimpangan status penduduk yang satu dengan yang lain dan menimbulkan status sosial antar masyarakat. 
Analisis regresi merupakan suatu model matematis yang dapat digunakan untuk mengetahui pola hubungan antara dua atau lebih variabel. Salah satu cara untuk menganalisis hubungan antara variabel dependen yang mempunyai kategori lebih dari dua, dengan beberapa variabel independen yang bersifat kontinu, kategorik atau keduanya adalah dengan menggunakan analisis regresi logistik multinomial.

Tujuan penelitian ini adalah menganalisis faktor yang berpengaruh terhadap pemilihan alat kontrasepsi. Selain itu, juga untuk mengetahui probabilitas pemilihan alat kontrasepsi wanita di Puskesmas Sungai Kakap. Pada penelitian ini yang dibahas adalah regresi logistik berganda yaitu regresi logistik multinomial dan alat kontrasepsi yang digunakan hanya pada wanita. Data yang digunakan dalam penelitian ini berupa data kuesioner tentang pemilihan alat kontrasepsi wanita.

Langkah pertama yaitu melakukan uji multikolinieritas, jika terdapat masalah multikolinearitas maka diatasi terlebih dahulu dengan cara melakukan transformasi pada data. Selanjutnya dibentuk variabel rancangan, pembentukan variabel rancangan dilakukan karena variabel independen ada yang bersifat kategori. Setelah dibentuk variabel rancangan mencari taksiran parameter dari model. Langkah selanjutnya yaitu melakukan uji signifikansi parameter model. Uji signifikansi terdiri dari dua tahapan, yaitu uji signifikansi parameter model secara simultan dan uji signifikansi parameter model secara parsial.

Uji signifikansi parameter model secara simultan dilakukan dengan uji rasio likelihood. Uji rasio likelihood digunakan untuk mengetahui apakah ada variabel independen yang berpengaruh pada model. Selanjutnya dilakukan uji signifikansi parameter model secara parsial dengan uji Wald karena terdapat variabel independen yang berpengaruh pada model. Uji Wald digunakan untuk mengetahui variabel independen mana yang berpengaruh pada model. Setelah diperoleh model dengan parameter yang signifikan, maka selanjutnya diperoleh hasil probabilitas.

\section{REGRESI LOGISTIK MULTINOMIAL}

Model regresi logistik digunakan untuk menganalisis variabel dependen yang bertipe kategorik. Regresi logistik dapat digunakan untuk menguji probabilitas terjadinya variabel dependen sehingga dapat diprediksi dengan variabel independennya. Sedangkan regresi logistik multinomial adalah sebuah analisis regresi untuk menyelesaikan masalah dimana variabel dependennya mempunyai kategorik lebih dari dua dengan beberapa variabel independen. Bentuk persamaan regresi logistik multinomial ke $j$ kategori adalah sebagai berikut [2]:

$$
\begin{aligned}
\pi_{0}(x) & =\frac{1}{1+\mathrm{e}^{g 1(x)}+\mathrm{e}^{g 2(x)}+\cdots+\mathrm{e}^{g j-i(x)}} \\
\pi_{1}(x) & =\frac{\mathrm{e}^{g 1(x)}}{1+\mathrm{e}^{g 1(x)}+\mathrm{e}^{g 2(x)}+\cdots+\mathrm{e}^{g j-i(x)}} \\
\quad & \\
\pi_{j-1}(x) & =\frac{\mathrm{e}^{g j-1(x)}}{1+\mathrm{e}^{g 1(x)}+\mathrm{e}^{g 2(x)}+\cdots+\mathrm{e}^{g j-i(x)}}, \mathrm{j}=1,2, \ldots \cdots
\end{aligned}
$$

dengan :

$$
\begin{aligned}
g_{1} & =\beta_{10}+\beta_{11} x_{1}+\beta_{12} x_{2}+\cdots+\beta_{1 p} x_{p} \\
g_{2} & =\beta_{20}+\beta_{21} x_{1}+\beta_{22} x_{2}+\cdots+\beta_{2 p} x_{p} \\
\vdots & \\
g_{j-1}(x) & =\beta_{(j-1) 0}+\beta_{(j-1) 1} x_{1}+\beta_{(j-1) 2} x_{2}+\cdots+\beta_{(j-1) p} x_{p}
\end{aligned}
$$

Mengetahui pengaruh dari variabel independen dilakukan uji signifikansi secara simultan dan secara parsial sebagai berikut [2] : 


\section{UJI SIMULTAN}

Uji simultan dilakukan untuk mengetahui apakah terdapat variabel independen yang berpengaruh signifikan terhadap variabel dependen, dengan hipotesis:

$H_{0}$ : tidak terdapat satupun variabel independen yang berpengaruh secara signifikan terhadap variabel dependen

$H_{1}$ : minimal terdapat salah satu variabel independen yang berpengaruh secara signifikan terhadap variabel dependen

Statistik uji [2]:

$$
G=-2 \ln \left[\frac{\text { likelihood tanpa variabel independen }}{\text { likelihood dengan variabel independen }}\right]
$$

Statistik uji $G$ berdistribusi Chi-Square dengan derajat bebas $v=(j-1) \sum_{b=1}^{m}\left(C_{b}-1\right)$, dengan $C_{b}$ adalah banyaknya kategori variabel independen ke- $b, b=1,2, \ldots, m$, sedangkan $j$ adalah banyaknya kategori variabel dependen.

Kriteria Uji:

Tolak $H_{0}$ jika $G \geq \chi_{\alpha, v}^{2}$, dengan $\alpha$ adalah tingkat signifikansi yang dipilih.

\section{UJI PARSIAL}

Uji parsial digunakan untuk menguji signifikansi masing-masing parameter $\beta_{j k}$, dengan hipotesis:

$H_{0}$ : tidak terdapat variabel independen yang berpengaruh secara signifikan terhadap variabel dependen

$H_{1}$ : terdapat variabel independen yang berpengaruh secara signifikan terhadap variabel dependen Statistik uji yang gunakan adalah uji Wald sebagai berikut [2]:

$$
W_{j k}=\left[\frac{\hat{\beta}_{j k}}{S \hat{E}\left(\hat{\beta}_{j k}\right)}\right]^{2}
$$

$S \hat{E}\left(\hat{\beta}_{j k}\right)$ adalah estimasi standar error dari $\hat{\beta}_{j k}$. Statistik uji Wald berdistribusi Chi-Square, sehingga pengambilan keputusan dilakukan perbandingan dengan derajat bebas 1 atau biasa ditulis $W_{j k} \sim \chi_{1, \alpha}^{2}$. Setelah dilakukan uji simultan dan uji parsial selanjutnya akan dilakukan uji kesesuaian model untuk mengetahui kesesuaian model antara variabel dependen dan variabel independen.

\section{STUDI KASUS}

Populasi dalam penelitian ini adalah semua pengguna alat kontrasepsi di Puskesmas Sungai Kakap. Banyak responden yang diambil dalam penelitian ini yaitu 150 responden. Proses pengumpulan data pada penelitian ini adalah dengan menggunakan pengisian kuesioner. Pengambilan sampel dilakukan dengan menggunakan non probability sampling, yaitu teknik purpose sampling dan teknik accidental sampling. Hal ini dikarenakan kerangka sampel yang tidak tersedia. Dalam penelitian ini diambil sampel pengguna alat kontrasepsi dan kebetulan ada di Puskesmas Sungai Kakap.

Tabel 1 Ukuran Sampel Peserta KB Wanita

\begin{tabular}{lc}
\hline Jenis Kontrasepsi & Sampel \\
\hline IUD & 13 \\
MOW & 2 \\
IMPLANT & 9 \\
SUNTIK & 81 \\
PIL & 45 \\
Total & 150 \\
\hline
\end{tabular}


Variabel dependen yang digunakan adalah jenis alat kontrasepsi pada wanita yang dipakai pada responden dan masih dipakai pada saat dilakukan penelitian yaitu, IUD, MOW, implant, suntik dan pil. Variabel independennya adalah faktor-faktor yang diduga berpengaruh dalam penggunaan alat kontrasepsi.

Tabel 2 Variabel Independen Penelitian

\begin{tabular}{|c|c|c|c|}
\hline No & Variabel Independen & Kode & Kategori \\
\hline \multirow[t]{2}{*}{1.} & \multirow[t]{2}{*}{ Umur Ibu $\left(X_{1}\right)$} & 0 & Umur $\leq 30$ Tahun \\
\hline & & 1 & Umur > 30 Tahun \\
\hline \multirow[t]{2}{*}{2.} & \multirow[t]{2}{*}{$\begin{array}{l}\text { Jenis Pekerjaan Ibu } \\
\qquad\left(X_{2}\right)\end{array}$} & 0 & $\begin{array}{l}\text { Kelompok pekerjaan terampil yang terdiri dari } \\
\text { PNS/Pensiunan, Pegawai Swasta dan Wiraswasta }\end{array}$ \\
\hline & & 1 & $\begin{array}{l}\text { Kelompok pekerjaan tidak terampil yang terdiri dari ibu } \\
\text { rumah tangga, petani dan buruh }\end{array}$ \\
\hline \multirow[t]{4}{*}{3.} & \multirow[t]{4}{*}{ Pendidikan Suami $\left(X_{3}\right)$} & 0 & SD \\
\hline & & 1 & SMP \\
\hline & & 2 & SMA \\
\hline & & 3 & Diploma/Perguruan Tinggi \\
\hline \multirow[t]{2}{*}{4.} & \multirow[t]{2}{*}{$\begin{array}{l}\text { Jenis Pekerjaan Suami } \\
\qquad\left(X_{4}\right)\end{array}$} & 0 & $\begin{array}{l}\text { Kelompok pekerja terampil yang terdiri dari } \\
\text { PNS/Pensiunan, Pegawai Swasta dan Wiraswasta }\end{array}$ \\
\hline & & 1 & $\begin{array}{l}\text { Kelompok pekerja tidak terampil yang terdiri dari petani, } \\
\text { buruh, tukang becak, supir angkot, nelayan }\end{array}$ \\
\hline \multirow[t]{2}{*}{5.} & \multirow{2}{*}{$\begin{array}{l}\text { Jumlah anak hidup } \\
\left(X_{5}\right)\end{array}$} & 0 & Jumlah anak hidup $\leq 2$ anak \\
\hline & & 1 & Jumlah anak hidup $>2$ anak \\
\hline \multirow[t]{2}{*}{6.} & \multirow{2}{*}{$\begin{array}{l}\text { Umur anak terakhir } \\
\qquad\left(X_{6}\right)\end{array}$} & 0 & Umur $\leq 5$ tahun \\
\hline & & 1 & Umur $>5$ tahun \\
\hline \multirow[t]{2}{*}{7.} & \multirow[t]{2}{*}{$\begin{array}{l}\text { Rencana Kehamilan } \\
\qquad\left(X_{7}\right)\end{array}$} & 1 & $\begin{array}{l}\text { "Tidak" yaitu apabila responden tidak menginkan adanya } \\
\text { kehamilan lagi }\end{array}$ \\
\hline & & 0 & $\begin{array}{l}\text { "Ya" yaitu apabila responden mengingkan adanya } \\
\text { kehamilan lagi }\end{array}$ \\
\hline
\end{tabular}

\section{UJI MULTIKOLINEARITAS}

Pada analisis regresi logistik multinomial, dibutuhkan data yang tidak terdapat masalah multikolinearitas. Cara untuk mengetahui ada atau tidaknya multikolinearitas antar variabel dapat digunakan nilai Variance Inflation Factor (VIF) dengan menggunakan rumus sebagai berikut [3]:

$$
V I F=\frac{1}{1-R^{2}}
$$

Dengan kriteria pengujian jika nilai $V I F<10$ dapat disimpulkan bahwa tidak terdapat multikolinearitas antar variabel, tetapi apabila nilai $V I F>10$ berarti terdapat multikolinearitas. Tabel 3 menunjukkan nilai VIF dengan meggunakan bantuan software spss.

Tabel 3 Nilai Variance Inflasion Factors (VIF)

\begin{tabular}{cc}
\hline Variabel & $V I F$ \\
\hline$X_{1}$ & 1,691 \\
$X_{2}$ & 1,031 \\
$X_{3}$ & 1,344 \\
\hline
\end{tabular}




\begin{tabular}{cc}
\hline Variabel & $V I F$ \\
\hline$X_{4}$ & 1,222 \\
$X_{5}$ & 1,138 \\
$X_{6}$ & 1,140 \\
$X_{7}$ & 1,670 \\
\hline
\end{tabular}

Tabel 3 menunjukkan bahwa nilai $V I F<10$ untuk semua variabel independen, sehingga data dapat dikatakan tidak memiliki masalah multikolinearitas karena memenuhi syarat berdasarkan nilai VIF. Selanjutnya dilakukan uji Chi-Square untuk mengetahui hubungan antara variabel dependen dengan variabel independen.

\section{UJI CHI-SQUARE}

Sebelum menerapkan model regresi logistik multinomial pada data yang diperoleh terlebih dahulu dilakukan uji chi-square untuk mengetahui apakah terdapat hubungan antara variabel dependen dengan variabel independen. Tabel 4 menunjukkan variabel independen yang berpengaruh terhadap variabel dependen. Untuk melihat hasil dari perhitungan software spss.

Tabel 4 Nilai Statistik Uji Chi-Square Pertama

\begin{tabular}{ccccc}
\hline $\begin{array}{c}\text { Variabel } \\
\text { Independen }\end{array}$ & $\begin{array}{c}\text { Chi- } \\
\text { Square }\end{array}$ & $\begin{array}{c}\text { Chi- } \\
\text { Square } \\
\text { Tabel }\end{array}$ & Sig. & Keputusan \\
\hline$x_{1}$ & 18,443 & 9,49 & 0,001 & $H_{0}$ ditolak \\
$x_{2}$ & 2,055 & 9,49 & 0,726 & $H_{0}$ diterima \\
$x_{3}$ & 42,184 & 21,03 & 0,000 & $H_{0}$ ditolak \\
$x_{4}$ & 16,044 & 9,49 & 0,003 & $H_{0}$ ditolak \\
$x_{5}$ & 16,049 & 9,49 & 0,003 & $H_{0}$ ditolak \\
$x_{6}$ & 56,050 & 9,49 & 0,047 & $H_{0}$ ditolak \\
$x_{7}$ & 26,260 & 9,49 & 0,000 & $H_{0}$ ditolak \\
\hline
\end{tabular}

Tabel 4 menunjukkan bahwa ada 6 variabel independen yang memiliki hubungan dengan variabel dependen, yaitu umur ibu, pendidikan suami, pekerjaan suami, jumlah anak hidup, umur anak terakhir, dan rencana hamil. Hal tersebut ditunjukkan dengan nilai sig. $<0.05$. Hasil penelitian uji chi-square terdapat nilai ecpected count kurang dari 5, yaitu pada alat kontrasepsi IUD-MOW-Implant. Sehingga untuk analisis selanjutnya, dilakukan penggabungan sampel antara IUD, MOW dan Implant dan nama variabel IUD-MOW-Implant. Jadi ada 3 variabel dependen yang digunakan untuk analisis regresi logistik, berikut hasil uji chi-square dengan variabel dependen IUD-MOW-Implant, suntik, dan pil.

Tabel 5 Nilai Statistik Uji Chi-Square Kedua

\begin{tabular}{ccccc}
\hline $\begin{array}{c}\text { Variabel } \\
\text { Independen }\end{array}$ & $\begin{array}{c}\text { Chi- } \\
\text { Square }\end{array}$ & $\begin{array}{c}\text { Chi-Square } \\
\text { Tabel }\end{array}$ & Sig. & Keputusan \\
\hline$x_{1}$ & 12,789 & 7,815 & 0,002 & $H_{0}$ ditolak \\
$x_{4}$ & 9,688 & 7,815 & 0,008 & $H_{0}$ ditolak \\
$x_{5}$ & 9,367 & 7,815 & 0,009 & $H_{0}$ ditolak \\
$x_{7}$ & 19,453 & 7,815 & 0,000 & $H_{0}$ ditolak \\
\hline
\end{tabular}

Pada Tabel 5 terlihat bahwa seluruh nilai chi-square hitung lebih besar dari chi-square tabel atau nilai probabilitas lebih kecil dari 0.05 . Sehingga dapat dikatakan bahwa variabel umur ibu, pekerjaan suami, jumlah anak hidup, dan rencana hamil memiliki ketergantungan terhadap penggunaan alat kontrasepsi. 


\section{ANALISIS REGRESI LOGISTIK MULTINOMIAL}

Penelitian ini, variabel dependennya adalah alat kontrasepsi yang digunakan wanita di Puskesmas Sungai Kakap, dibagi menjadi 3 kategori, yaitu:

$Y=0$ untuk variabel dependen dengan kategori IUD-MOW-implant (sebagai pembanding)

$Y=1$ untuk variabel dependen dengan kategori suntik

$Y=2$ untuk variabel dependen dengan kategori pil

$g_{1}$ adalah fungsi logit untuk alat kontrasepsi suntik dan $g_{2}$ adalah fungsi logit untuk alat kontrasepsi pil. Fungsi logit yang diperoleh dari estimasi parameter adalah:

$g_{1}=5,592-1,948 x_{1}-1,448 x_{4}-2,423 x_{5}-2,477 x_{7}$

$g_{2}=2,628-1,434 x_{4}$

Setelah diperoleh nilai estimasi parameter, selanjutnya dilakukan uji signifikansi.

Uji simultan dilakukan untuk mengetahui apakah terdapat variabel independen yang berpengaruh signifikan terhadap variabel dependen, dengan hipotesis:

$H_{0}$ : tidak terdapat variabel independen yang berpengaruh secara signifikan terhadap variabel dependen

$H_{1}$ : minimal terdapat variabel independen yang berpengaruh secara signifikan terhadap variabel dependen.

Hasil uji simultan dapat dilihat pada tabel 6 dengan menggunakan bantuan software spss.

\section{Tabel 6 Uji Simultan}

\begin{tabular}{lcccc}
\hline \multirow{2}{*}{ Model } & \multicolumn{2}{c}{$\begin{array}{l}\text { Likelihood } \\
\text { Ratio Tests }\end{array}$} & \multicolumn{2}{c}{ Likelihood Ratio Tests } \\
\cline { 2 - 5 } & $\begin{array}{l}-2 \text { Log } \\
\text { Likelihood }\end{array}$ & $\begin{array}{c}\text { Chi- } \\
\text { Square }\end{array}$ & df & \multirow{2}{*}{ Sig. } \\
& 148,120 & & & \\
Intercept Only & 93,823 & 54,297 & 8 &, 000 \\
Final & & & & \\
\hline
\end{tabular}

Berdasarkan Tabel 6 diperoleh nilai sig. $=0,000<\alpha=0,05$ yang berarti $H_{0}$ ditolak, yang artinya minimal terdapat salah satu variabel independen yang berpengaruh secara signifikan terhadap variabel dependen.

Uji parsial digunakan untuk menguji signifikansi masing-masing parameter $\beta_{j k}$, dengan hipotesis:

$H_{0}$ : tidak terdapat variabel independen yang berpengaruh secara signifikan terhadap variabel dependen

$H_{1}$ : terdapat variabel independen yang berpengaruh secara signifikan terhadap variabel dependen

Statistik uji Wald ini berdistribusi Chi-Square dengan derajat bebas 1 dengan $\alpha=0,05$.

Hasil penelitian menunjukkan bahwa pada fungsi logit 1 (perbandingan antara IUD-MOW-Implant dan suntik) terlihat ada 4 variabel yang berpengaruh terhadap model yaitu umur ibu, pekerjaan suami, jumlah anak hidup, dan rencana hamil. Sedangkan pada fungsi logit 2 (perbandingan antara IUDMOW-Implant dan pil) hanya variabel pekerjaan suami yang berpengaruh, sehingga diperoleh model regresi logistik multinomial sebagai berikut:

$$
\begin{aligned}
& \pi_{0}=\frac{1}{1+e^{5,592-1,948 \times 1-1,448 \times 4-2,423 \times 5-2,477 \times 7}+e^{2,628-1,434 \times 4}} \\
& \pi_{1}=\frac{e^{5,592-1,948 \times 1-1,1448 \times 4-2,423 \times 5-2,477 \times 7}}{1+e^{5,592-1,948 \times 1-1,448 \times 4-2,423 \times 5-2,477 \times 7}+e^{2,628-1,434 \times 4}} \\
& \pi_{2}=\frac{e^{2,628-1,434 \times 4}}{1+e^{5,592-1,948 \times 1-1,448 \times 4-2,423 \times 5-2,477 \times 7}+e^{2,628-1,434 \times 4}}
\end{aligned}
$$

Untuk mengetahui probabilitas kontrasepsi yang memiliki probabilitas paling besar untuk dipilih oleh kelompok umur ibu, pekerjaan suami, anak hidup, dan rencana hamil maka digunakan estimasi 
probabilitas variabel dependen. Sebagai contoh, untuk kelompok usia (umur $\leq 30$ tahun) dikodekan dengan 0 , pekerjaan suami terampil dikodekan dengan 0 , jumlah anak hidup $\leq 2$ dikodekan dengan 0 , dan tidak ada rencana hamil dikodekan dengan 1 .

Berdasarkan hasil probabilitas tersebut dapat dikatakan bahwa probabilitas variabel independen berumur $\leq 30$ tahun dengan pekerjaan suami terampil, jumlah anak hidup $\leq 2$, dan tidak memiliki rencana hamil lagi memilih IUD-MOW-Implant sebagai alat kontrasepsi sebesar 0,0353\%, memilih suntik $94,756 \%$, dan memilih pil sebesar 4,891\%. Hasil estimasi probabilitas selengkapnya dapat dilihat pada Tabel 7.

Tabel 7 Estimasi Probabilitas Pemilihan Alat Kontrasepsi

\begin{tabular}{|c|c|c|c|c|c|c|}
\hline \multirow[t]{2}{*}{ Umur Ibu } & \multirow{2}{*}{$\begin{array}{l}\text { Pekerjaan } \\
\text { Suami }\end{array}$} & \multirow{2}{*}{$\begin{array}{c}\text { Jumlah } \\
\text { Anak } \\
\text { Hidup }\end{array}$} & \multirow{2}{*}{$\begin{array}{c}\text { Rencana } \\
\text { Hamil }\end{array}$} & \multicolumn{3}{|c|}{ Jenis Kontrasepsi } \\
\hline & & & & $\begin{array}{l}\text { IUD-MOW- } \\
\text { Implant }\end{array}$ & Suntik & Pil \\
\hline \multirow{8}{*}{$\leq 30$ Tahun } & \multirow{4}{*}{$\begin{array}{c}\text { Tidak } \\
\text { Terampil }\end{array}$} & \multirow[t]{2}{*}{$\leq 2$} & ada & 0,00353 & 0,94756 & 0,04891 \\
\hline & & & Tidak Ada & 0,02675 & 0,60283 & 0,37042 \\
\hline & & \multirow[t]{2}{*}{$>2$} & ada & 0,02589 & 0,61568 & 0,35843 \\
\hline & & & Tidak Ada & 0,05937 & 0,11860 & 0,82203 \\
\hline & \multirow{4}{*}{ Terampil } & \multirow[t]{2}{*}{$\leq 2$} & ada & 0,01485 & 0,93616 & 0,04899 \\
\hline & & & Tidak Ada & 0,10420 & 0,55189 & 0,34390 \\
\hline & & \multirow[t]{2}{*}{$>2$} & ada & 0,10111 & 0,56521 & 0,33368 \\
\hline & & & Tidak Ada & 0,20965 & 0,09844 & 0,69191 \\
\hline \multirow{8}{*}{ > 30 Tahun } & \multirow{4}{*}{$\begin{array}{c}\text { Tidak } \\
\text { Terampil }\end{array}$} & \multirow[t]{2}{*}{$\leq 2$} & ada & 0,01884 & 0,72036 & 0,26080 \\
\hline & & & Tidak Ada & 0,05538 & 0,17789 & 0,76674 \\
\hline & & \multirow[t]{2}{*}{$>2$} & ada & 0,05483 & 0,18592 & 0,75924 \\
\hline & & & Tidak Ada & 0,06609 & 0,01882 & 0,91509 \\
\hline & \multirow{4}{*}{ Terampil } & \multirow[t]{2}{*}{$\leq 2$} & ada & 0,07525 & 0,67641 & 0,24834 \\
\hline & & & Tidak Ada & 0,19781 & 0,14935 & 0,65283 \\
\hline & & \multirow[t]{2}{*}{$>2$} & ada & 0,19619 & 0,15635 & 0,64747 \\
\hline & & & Tidak Ada & 0,22898 & 0,01533 & 0,75569 \\
\hline
\end{tabular}

Hasil estimasi probabilitas secara lengkap pada Tabel 7, terlihat bahwa jenis kontrasepsi suntik paling banyak dipilih pada kelompok ibu yang berusia kurang dari atau sama dengan 30 tahun dengan jenis pekerjaan suami tidak terampil, jumlah anak kurang dari atau sama dengan 2 orang dan memiliki rencana hamil, untuk memilih suntik sebesar 94,756\%. Jenis kontrasepsi IUD-MOW-Implant paling banyak pada kelompok ibu yang berusia diatas 30 tahun dengan jenis pekerjaan suami terampil, jumlah anak diatas 2 orang dan tidak memiliki rencana hamil, untuk memilih IUD-MOW-Implant sebesar $22,898 \%$. Sedangkan untuk jenis kontrasepsi pil paling banyak dipilih pada kelompok ibu yang berusia diatas 30 tahun dengan jenis pekerjaan suami tidak terampil, jumlah anak diatas 2 orang dan tidak memiliki rencana hamil, untuk memilih pil adalah 91,509\%.

\section{PENUTUP}

Berdasarkan hasil analisis maka diperoleh kesimpulan sebagai berikut:

1. Probabilitas seorang ibu dalam menentukan pemilihan alat kontrasepsi dipengaruhi oleh umur ibu, pekerjaan ayah, jumlah anak hidup, dan rencana hamil.

2. Probabilitas kelompok ibu yang berusia diatas 30 tahun dengan jenis pekerjaan suami terampil, jumlah anak diatas 2 orang dan tidak memiliki rencana hamil, untuk memilih iud-mow-implant adalah 22,898\%. Probabilitas kelompok ibu yang berusia kurang dari atau sama dengan 30 tahun dengan jenis pekerjaan suami tidak terampil, jumlah anak kurang dari atau sama dengan 2 orang dan memiliki rencana hamil, untuk memilih suntik adalah 94,756\%. Probabilitas kelompok ibu yang berusia diatas 30 tahun dengan jenis pekerjaan suami tidak terampil, jumlah anak diatas 2 orang dan tidak memiliki rencana hamil, untuk memilih pil adalah 91,509\%. 


\section{DAFTAR PUSTAKA}

[1] Kementrian Perencanaan Pembangunan Nasional [Internet]. [updated 2019; cited 2019 Jul 29] available from: http://databoks.katadata.co.id/

[2] Sulistio, E. Penerapan Regresi Logistik Multinomial Pada Pemilihan Alat Kontrasepsi Wanita. Media Statistika. 2010. 3:31-40.

[3] Anggraeni, W.R. Estimasi Parameter Regresi Ridge Untuk Mengatasi Mutikolinearitas. Jurnal Ilmiah Mat. Stat. dan Terapannya. 2018. 4:295-302.

\section{NOVIANTI}

SETYO WIRA RIZKI
: Jurusan Matematika FMIPA UNTAN, Pontianak Novianti0611@gmail.com

: Jurusan Matematika FMIPA UNTAN, Pontianak Setyo.wirarizki@math.untan.ac 